\title{
The Feasibility of E-Learning Media on Anecdote Text Material for X Grade Students of Senior High School Harapan 3 Delitua, Indonesia
}

\author{
Zulfikar Alamsyah ${ }^{\mathbf{1}}$, Abdurahman Adisaputera ${ }^{2}$, Isda Pramuniati ${ }^{2}$ \\ ${ }^{1}$ Master Student in State University of Medan (Unimed), Medan, Indonesia \\ ${ }^{2}$ Lecturer in in State University of Medan (Unimed), Medan, Indonesia \\ zulfikaralamsyah43@gmail.com
}

\begin{abstract}
The feasibility of anecdote text e-learning based learning media is based on the validation test of material experts and design experts. After being validated, the research products can be tested on individual students, small groups and limited groups. The following will be explained the feasibility test of e-learning based text and text learning media. Research methods in this research plan include: location and time of study, population and sample of research, research design, operational definition, research procedures, types of data, techniques and data collection instruments. The conclusion is that the use of e-learning based anecdote text learning media is more effective than non-e-learning based learning, this can be seen from the average results of the pretest and posttest and the achievement of the indicator value of students in using e-learning learning media.
\end{abstract}

Keywords: Feasibility; e-learning media; anecdote text; student.

\section{Introduction}

Indonesian language is a compulsory and important subject in school because by learning Indonesian language, students are expected to be able to communicate properly and correctly and share experiences with others, be able to live up to Indonesian language and literature according to situations and conditions such as understanding and appreciating anecdote texts which have messages that are want to be conveyed by the writer. Indirectly by studying Indonesian language and literature subjects can improve intellectual abilities in communicating both oral and written.

The results of interviews with two Indonesian language teachers at Harapan 3 Junior High School of Delitua, namely Asmawati, M.Pd and Andre Sudaryanto, S.S. that learning media used are still conventional learning media, such as textbooks and power point learning media. Determining learning media must pay attention to the needs and characteristics of students because not all students are able to understand lessons only come from textbooks and this teaching material is not necessarily useful if applied in the classroom.

Based on observations at Harapan 3 Senior High School of Delitua, the school determines KKM for anecdote text material 75. The phenomenon that occurs is $60 \%$ of students do not achieve the KKM value and $40 \%$ of students reach the KKM value. The problems faced, students have difficulty in determining the structure and analyzing criticism in anecdote texts. The inability of students in determining the structure and analyzing criticism of anecdote texts causes the low value of students in the learning process and consequently $60 \%$ of students do not achieve the KKM value.

Following is one of the texts analyzed based on the anecdote structure by students "Compassion for Parents". This text tells how to treat parents well, this text has elements of abstraction, orientation, crisis, reaction, and code and students difficulty in determining the elements of this text. The old man who lives with children, son-in-law and grandchildren of 6 years old (abstraction), the habit of eating dinner at the child's home, the old man often eats messy (orientation), the old man is given a small separate table in the corner, with cutlery anti- 
cut (crisis), a 6 years old grandchildren makes a separate table replica (reaction), a 6-years old grandchildren reveals that someday it will make a separate table also for her father and mother (coda), adults who are ashamed of being criticized by children (Humor).

This is a very interesting phenomenon considering the observed school is a superior school, consisting of students who have good ability and intelligence. Based on observations and interviews it turns out that so far the teacher presents Indonesian language learning materials, especially in anecdote text material still using textbooks and whiteboard learning media and sometimes using power point, it causes the learning provided to be less attractive to students.

\section{Review of Literature}

\subsection{The Nature of Learning Resources}

The rapid flow of information that develops in the community makes everyone required to work hard in order to keep abreast of the times. The phenomenon of the spread of the internet has entered every aspect of people's lives. Currently all human affairs and needs can be said to be always connected to the network / internet connection.

Likewise in learning at schools, to get optimal learning outcomes, teachers are required not only to utilize learning resources in the classroom, but teachers must be able to explore and find other learning resources that are outside the classroom / school. Teachers are required not only to use learning resources that only exist in schools such as textbooks but teachers are also required to obtain or find teaching materials from various sources such as newspapers, magazines, tabloids and most importantly teachers must be able to use computers and utilize internet connections.

This can be seen from varieties of learning resources that can be used and utilized to support the effectiveness of learning outcomes, and each must be adapted to the usefulness and material being taught. Choosing learning resources must also view the uses and learning objectives to be achieved, the following classification of learning resources according to Istiarni (2017: 73) is as follows:

1. Humans (people) that is people who deliver learning messages directly.

2. Material that is something that contains a message of learning.

3. Scope (setting), that is the space and place when resources can interact with students.

4. Tools and equipment (tools) that is all things that can be used to help teachers, while teaching materials are all things that contain a message that will be delivered to students.

5. Activities that is all actions planned by the teacher to facilitate student activities for learning.

E-learning media for the digital era as it is currently needed by students, because if students do not understand the teacher's explanation, students can open websites and learn independently. These five classifications are interrelated and inseparable and require teacher creativity in developing them, with strategies, innovation and creativity, learning is expected to be more targeted and precise so that learning indicators can be met and the quality of student learning can improve properly. More details can be seen in the following picture: 


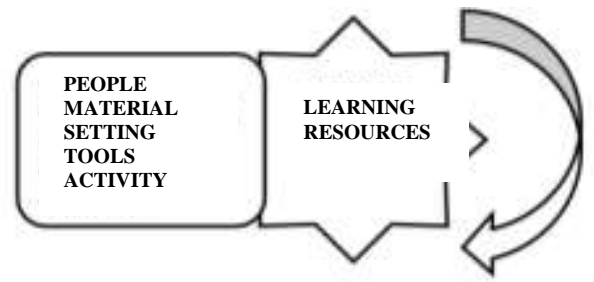

Figure 1. Variety of Learning Resources Istiarni (2017:73)

\subsection{Anecdote Texts}

The text is a compulsory subject presented in the 2013 curriculum, specifically for the 2013 curriculum the government implanted three domains at once in each of its lessons: the realm of attitude, cognitive, and psychomotor that have been updated with each other through this competency. Based on these three competencies each student is expected to be able to become an independent student throughout his life and be able to fend off an increasing wave of globalization, they will be an important component to realizing a learning community.

The government began to create a program of formal education so that school-age children became familiar with the reading movement. The government is also implementing a SLM (school literacy movement) system. In this case anecdote text is included in one of the types of texts studied by class $\mathrm{X}$ students, literally anecdote text can be interpreted as text in the form of innuendo but has a humorous side.

According to Beslina (2015: 50) anecdote is a short and funny or interesting story that illustrates the events or actual people. This is in line with the opinion of Dyah (2017: 12) anecdote is a form of writing used to convey criticism, but not in a rude and hurtful way. According to Neni (2018: 714) anecdote texts are text in the form of stories, which contain humor and criticism, because they contain criticism, anecdotes is often originate from factual stories with well-known real figures. According to the Ministry of Education and Culture (2015: 103) anecdote is short and funny stories that are used to convey criticism through humorous insinuations about events involving people or the behavior of public the figures.

From the above opinion it can be concluded that anecdote text is a text written by a writer to insinuate and criticize the behavior of public figures or the public. Anecdote text has a function as a way to convey innuendo, criticism but in a subtle and humorous way, herein lies the intelligence of a writer, because an author conveys an experience with a series of words, but has deep meaning, according to Safwan (2017: 33) in the world of imagination, humans try to replay their experiences and impressions after studying the inner treasury and the reality of society.

\subsection{E-Learning}

Along with the rapid advancement of information technology nowadays, education has shifted to learning based on e-learning and the need for IT-based learning is inevitable. Elearning is a system or concept of education that utilizes information technology in the teaching and learning process, so that it can facilitate students or students in obtaining the information needed, because it is rarely encountered by students who do not use smartphones, either based on Android or IOS.

Learning methods that are increasingly developing towards technological progress must be put to good use by teachers and teachers must master the advancement of internet / webbased technology which is also called E-Learning. Teachers are also required to have the ability 
in technological literacy. The goal of the 21 st century education is to be able to create people who understand and are able to use technology as students' experiences and needs.

Technological advances, a teacher is required to have the ability and ability to use computer informatics technology to obtain various information, in line with Susan's opinion (2007: 5) given the evolving nature of technology, interactive communication between preservice teachers and teachers in positions, facilitators Professional development and educators, teachers are very important to provide meaningful technology related experiences for all children.

The skills required by workers in the 21 st century are certainly different from those of the industrial age, because rapid technological advances certainly affect the mindset and development of new types of work. These skills according to Galbert in Wasis (2018: 5) skills include: communication skills, creativity and innovation, cooperation and empowerment, information technology literacy, visual ability, problem solving, decision making, development and management of knowledge and intelligence. Technology literacy is currently not only developing in the world of work, but also propagating in the world of education, it is possible for future education to have a digital concept as technology advances.

\section{Research Method}

Research methods in this research plan include: location and time of study, population and sample of research, research design, operational definition, research procedures, types of data, techniques and data collection instruments. The components covering the research method will be explained below.

This research was conducted at Senior High School of Harapan 3 Delitua in 2019/2020 academic year in the even semester, the subject of anecdote texts in this time frame included textbook analysis activities, proposal preparation, making e-learning based learning media, data collection, data analysis and writing final research report.

\section{Discussion}

The feasibility of anecdote text e-learning based learning media is based on the validation test of material experts and design experts. After being validated, the research products can be tested on individual students, small groups and limited groups. The following will be explained the feasibility test of e-learning based text and text learning media.

Validation by material experts is intended to find out expert opinion regarding the feasibility of presenting the material and language contained in the e-learning based anecdote text media. Validation was conducted by Prof. Dr. Amrin Saragih, M.A., Ph. D. and Mr. Prof. Dr. Khairil Ansari, M.Pd. who are a lecturer in Indonesian language graduate program at Medan State University. This validation was carried out in order to obtain anecdote text elearning based learning media that has good quality and can improve Indonesian language learning at the high school level, especially on anecdote text material.

The results of the validation questionnaire showed that the material aspects of anecdote text e-learning based learning were declared "Excellent" with an average percentage of $96.87 \%$. The contents are declared eligible because they are on an average value above $75 \%$. Data about the feasibility of the material can be seen in table 1 below: 
Table 1. Validation Results of Material Expert on the Feasibility of the E-Learning based Anecdote text Content Learning media Media for X Grade Students of Senior High School Harapan 3 Delitua

\begin{tabular}{|c|c|c|c|}
\hline Sub Component & Indicator Assessments & Percentage & Criteria \\
\hline \multirow{3}{*}{$\begin{array}{l}\text { Material Compatibility } \\
\text { with KI and KD }\end{array}$} & $\begin{array}{l}\text { Suitability of basic } \\
\text { competencies and } \\
\text { indicators }\end{array}$ & 100 & Excellent \\
\hline & $\begin{array}{l}\text { Completeness of } \\
\text { anecdote text material } \\
\text { (Structure and } \\
\text { formulation of } \\
\text { language) }\end{array}$ & 100 & Excellent \\
\hline & $\begin{array}{l}\text { The extent of anecdote } \\
\text { text material }\end{array}$ & 100 & Excellent \\
\hline \multirow{8}{*}{ Material Accuracy } & $\begin{array}{l}\text { The accuracy of } \\
\text { anecdote text material }\end{array}$ & 100 & Excellent \\
\hline & $\begin{array}{l}\text { The accuracy of facts } \\
\text { and data }\end{array}$ & 100 & Excellent \\
\hline & $\begin{array}{l}\text { The accuracy of } \\
\text { examples and cases }\end{array}$ & 100 & Excellent \\
\hline & $\begin{array}{l}\text { The accuracy in } \\
\text { material explanation }\end{array}$ & 100 & Excellent \\
\hline & $\begin{array}{l}\text { The accuracy of the } \\
\text { video and illustrations }\end{array}$ & 100 & Excellent \\
\hline & Clarity of terms & 87.5 & Excellent \\
\hline & $\begin{array}{l}\text { Clarity of user } \\
\text { objectives }\end{array}$ & 100 & Excellent \\
\hline & $\begin{array}{l}\text { The accuracy of library } \\
\text { references }\end{array}$ & 87.5 & Excellent \\
\hline \multirow{4}{*}{ Material Updates } & $\begin{array}{l}\text { The suitability of the } \\
\text { material with the } \\
\text { development of science }\end{array}$ & 100 & Excellent \\
\hline & $\begin{array}{l}\text { Displays topics as } \\
\text { examples of anecdote } \\
\text { text }\end{array}$ & 87.5 & Excellent \\
\hline & $\begin{array}{l}\text { Video according to } \\
\text { everyday life }\end{array}$ & 87.5 & Excellent \\
\hline & & 100 & Excellent \\
\hline
\end{tabular}




\begin{tabular}{|l|l|l|l|} 
& $\begin{array}{l}\text { Use the latest text or } \\
\text { characters }\end{array}$ & & \\
\hline \multirow{5}{*}{ Encourage Curiosity } & Material winnings & 100 & Excellent \\
\cline { 2 - 4 } & Encourage curiosity & 100 & Excellent \\
\cline { 2 - 5 } & $\begin{array}{l}\text { Creating the ability for } \\
\text { ask }\end{array}$ & 100 & Excellent \\
\cline { 2 - 5 } & Encourage motivation & 100 & Excellent \\
\cline { 2 - 5 } & $\begin{array}{l}\text { Encourage the ability to } \\
\text { re-create anecdote text }\end{array}$ & 87.5 & Excellent \\
\hline Average & & & $\mathbf{9 6 . 8 7 5}$ \\
\hline
\end{tabular}

Table 2. The Percentage Criteria of indicators occurrence on E-Learning based Anecdote text learning media that have been developed as follows:

\begin{tabular}{|l|l|l|}
\hline No. & Answer & Score \\
\hline A & Excellent & $81 \% \leq \mathrm{X}<100 \%$ \\
\hline B & Good & $61 \% \leq \mathrm{X}<80 \%$ \\
\hline C & Enough & $41 \% \leq \mathrm{X}<60 \%$ \\
\hline D & Fair & $21 \% \leq \mathrm{X}<40 \%$ \\
\hline E & Unsatisfied & $0 \% \leq \mathrm{X}<20 \%$ \\
\hline
\end{tabular}

(Sugiyono, 2012: 118)

Table 3. Validation Results of Material Expert on the Feasibility of E-Learning based Anecdote text learning media Presentation for X Grade Students of Senior High School Harapan 3 Delitua

\begin{tabular}{|l|l|l|l|}
\hline $\begin{array}{l}\text { Sub } \\
\text { Component }\end{array}$ & Indicator Assessment & Percentage & Criteria \\
\hline \multirow{2}{*}{$\begin{array}{l}\text { Presentation } \\
\text { Techniques }\end{array}$} & $\begin{array}{l}\text { Systematic consistency } \\
\text { of presentation in } \\
\text { learning }\end{array}$ & 100 & Excellent \\
\cline { 2 - 4 } & Conformity of concepts & 100 & Excellent \\
\hline \multirow{2}{*}{$\begin{array}{l}\text { Presentation } \\
\text { of Learning } \\
\text { Materials }\end{array}$} & Student involvement & 87.5 & Excellent \\
\cline { 2 - 4 } & Centered on students & 87.5 & Excellent \\
\cline { 2 - 4 } & & 100 & Excellent \\
\hline
\end{tabular}




\begin{tabular}{|c|c|c|c|}
\hline & $\begin{array}{l}\text { Simplicity of } \\
\text { Presentation of Material }\end{array}$ & & \\
\hline & $\begin{array}{l}\text { Clarity in presentation } \\
\text { of material }\end{array}$ & 100 & Excellent \\
\hline & $\begin{array}{ll}\text { Demand students } & \text { solve } \\
\text { problems in video } \\
\text { illustrations }\end{array}$ & 87.5 & Excellent \\
\hline \multirow{3}{*}{$\begin{array}{l}\text { Completeness } \\
\text { of } \\
\text { Presentation }\end{array}$} & $\begin{array}{l}\text { Examples of questions } \\
\text { in each learning activity }\end{array}$ & 100 & Excellent \\
\hline & $\begin{array}{l}\text { Matter of practice in } \\
\text { learning material }\end{array}$ & 100 & Excellent \\
\hline & $\begin{array}{l}\text { Key answer to practice } \\
\text { questions }\end{array}$ & 100 & Excellent \\
\hline \multicolumn{2}{|l|}{ Average } & 96.25 & Excellent \\
\hline
\end{tabular}

Table 4. The Percentage Criteria of indicators occurrence on the feasibility of E-Learning based Anecdote text learning media that have been developed.

\begin{tabular}{|l|l|l|}
\hline No. & Answer & Score \\
\hline A & Excellent & $81 \% \leq \mathrm{X}<100 \%$ \\
\hline B & Good & $61 \% \leq \mathrm{X}<80 \%$ \\
\hline C & Enough & $41 \% \leq \mathrm{X}<60 \%$ \\
\hline D & Fair & $21 \% \leq \mathrm{X}<40 \%$ \\
\hline E & Unsatisfied & $0 \% \leq \mathrm{X}<20 \%$ \\
\hline
\end{tabular}

(Sugiyono, 2012: 118)

Table 5. Validation Results of Material Expert on the Feasibility of Language E-Learning based Anecdote text learning media for X Grade Students of Senior High School Harapan 3 Delitua

\begin{tabular}{|l|l|l|l|}
\hline \multirow{4}{*}{ Sub Component } & Indicator Assessment & Percentage & Criteria \\
\hline \multirow{5}{*}{ Straightforward } & The accuracy of the sentence & 100 & Excellent \\
\cline { 2 - 4 } & The effectiveness of the sentence & 100 & Excellent \\
\cline { 2 - 4 } & The rigidity of terms & 87.5 & Excellent \\
\cline { 2 - 4 } & The message readability & 100 & Excellent \\
\cline { 2 - 4 } & The correct use of language & 100 & Excellent \\
\cline { 2 - 4 } & $\begin{array}{l}\text { The ability to motivate the messages } \\
\text { / information }\end{array}$ & 100 & Excellent \\
\cline { 2 - 4 } & & &
\end{tabular}




\begin{tabular}{|l|l|l|l|} 
& $\begin{array}{l}\text { The ability to encourage the critical } \\
\text { thinking }\end{array}$ & 100 & Excellent \\
\hline $\begin{array}{l}\text { The suitability of students' } \\
\text { intellectual development }\end{array}$ & 87.5 & Excellent \\
${$\cline { 2 - 4 }$} \begin{array}{l}\text { The } \\
\text { emotional development }\end{array} }$ & 87.5 & Excellent \\
\hline $\begin{array}{l}\text { The suitability of the story with the } \\
\text { circumstances / facts }\end{array}$ & 87.5 & Excellent \\
\hline Average & & $\mathbf{9 5}$ & Excellent \\
\hline
\end{tabular}

Table 6. The Percentage Criteria of indicators occurrence on the E-Learning based Anecdote text learning that have been developed

\begin{tabular}{|l|l|l|}
\hline No. & Answer & Score \\
\hline A & Excellent & $81 \% \leq \mathrm{X}<100 \%$ \\
\hline B & Good & $61 \% \leq \mathrm{X}<80 \%$ \\
\hline C & Enough & $41 \% \leq \mathrm{X}<60 \%$ \\
\hline D & Fair & $21 \% \leq \mathrm{X}<40 \%$ \\
\hline E & Unsatisfied & $0 \% \leq \mathrm{X}<20 \%$ \\
\hline
\end{tabular}

(Sugiyono, 2012: 118)

Table 7. Validation Results of Design Experts on the Learning Media against the Aspects of Media Display in a Double-Based Anecdote Text

\begin{tabular}{|l|l|l|l|}
\hline No & Indicator Assessment & Percentage & Criteria \\
\hline 1 & Proportional Layout & 100 & Excellent \\
\hline 2 & The suitability of background selection & 87.5 & Excellent \\
\hline 3 & The appropriate color proportions & 87.5 & Excellent \\
\hline 4 & The suitability of letter selection & 100 & Excellent \\
\hline 5 & The appropriate font size selection & 100 & Excellent \\
\hline 6 & Video sound clarity & 100 & Excellent \\
\hline 7 & Interest in animated video shows & 100 & Excellent \\
\hline 8 & Interest in animation presentation & 100 & Excellent \\
\hline 9 & $\begin{array}{l}\text { The suitability of the animation with the } \\
\text { material }\end{array}$ & 87.5 & Excellent \\
\hline 10 & Interest in video examples & 100 & Excellent \\
\hline 11 & $\begin{array}{l}\text { The suitability of the video with the } \\
\text { material }\end{array}$ & 100 & Excellent \\
\hline 12 & Interest in the form of navigator & 100 & Excellent \\
\hline 13 & Display button consistency & 100 & Excellent \\
\hline 14 & Attractive cover design & 100 & Excellent \\
\hline
\end{tabular}




\begin{tabular}{|l|l|l|l|}
15 & $\begin{array}{l}\text { The completeness of information on the } \\
\text { outer packaging }\end{array}$ & 87.5 & Excellent \\
\hline Average & $\mathbf{9 6 . 6 6}$ & Excellent \\
\hline
\end{tabular}

Table 8. The Percentage Criteria of indicators occurrence on the E-Learning based Anecdote text learning that have been developed

\begin{tabular}{|l|l|l|}
\hline No. & Answer & Score \\
\hline A & Excellent & $81 \% \leq \mathrm{X}<100 \%$ \\
\hline B & Good & $61 \% \leq \mathrm{X}<80 \%$ \\
\hline C & Enough & $41 \% \leq \mathrm{X}<60 \%$ \\
\hline D & Fair & $21 \% \leq \mathrm{X}<40 \%$ \\
\hline E & Unsatisfied & $0 \% \leq \mathrm{X}<20 \%$ \\
\hline
\end{tabular}

(Sugiyono, 2012: 118)

Table 9. Validation Results of Learning Media Design Experts against Aspects of Programming an E-Learning Based Anecdote text Media

\begin{tabular}{|l|l|l|l|}
\hline No & Indicator Assessment & Percentage & Criteria \\
\hline 1 & Ease to run the program & 100 & Excellent \\
\hline 2 & Ease to select the program menu & 100 & Excellent \\
\hline 3 & Freedom to choose the material for lessons & 100 & Excellent \\
\hline 4 & Ease to interact with programs & 100 & Excellent \\
\hline 5 & $\begin{array}{l}\text { Ease to understand the structure of } \\
\text { navigation }\end{array}$ & 100 & Excellent \\
\hline 6 & Ease to navigate performance & 100 & Excellent \\
\hline 7 & The accuracy of the button reaction & 75 & Good \\
\hline 8 & Easy to search the page settings & 100 & Excellent \\
\hline 9 & Ease to run the animation settings & 87.5 & Excellent \\
\hline 10 & Operating system compatibility & 100 & Excellent \\
\hline 11 & Operating system access is speed & 100 & Excellent \\
\hline 12 & Program file capacity for easy duplication & 100 & Excellent \\
\hline 13 & Completeness of E-learning features & 100 & Excellent \\
\hline 14 & Ease to access the E-learning & 100 & Excellent \\
\hline 15 & Ease to access the anecdote texts & 100 & Excellent \\
\hline Average & $\mathbf{9 7 . 5 0}$ & Excellent \\
\hline
\end{tabular}

Table 10. The Percentage Criteria of indicators occurrence on the E-Learning based Anecdote text learning that have been developed

\begin{tabular}{|l|l|l|}
\hline No. & Answer & Score \\
\hline A & Excellent & $81 \% \leq X<100 \%$ \\
\hline B & Good & $61 \% \leq X<80 \%$ \\
\hline
\end{tabular}




\begin{tabular}{|l|l|l|}
\hline C & Enough & $41 \% \leq \mathrm{X}<60 \%$ \\
\hline D & Fair & $21 \% \leq \mathrm{X}<40 \%$ \\
\hline E & Unsatisfied & $0 \% \leq \mathrm{X}<20 \%$ \\
\hline
\end{tabular}

(Sugiyono, 2012: 118)

Table 11. Individual Trial Results of E-Learning Based Anecdote text Learning Media on X Grade Students of Senior High School Harapan 3 Delitua

\begin{tabular}{|c|c|c|c|c|}
\hline No & Question & Total & Percentage & Criteria \\
\hline 1 & $\begin{array}{l}\text { The appearance of e-learning is unique } \\
\text { and makes you interested in learning } \\
\text { Indonesian. }\end{array}$ & 10 & 83.33 & Excellent \\
\hline 2 & $\begin{array}{l}\text { This e-learning display has attractive } \\
\text { colors and images. }\end{array}$ & 9 & 75 & Good \\
\hline 3 & $\begin{array}{l}\text { This e-learning display has color } \\
\text { variations. }\end{array}$ & 8 & 66.66 & Good \\
\hline 4 & $\begin{array}{l}\text { The language used in e-learning is } \\
\text { simple and easy for you to understand. }\end{array}$ & 11 & 91.66 & Excellent \\
\hline 5 & $\begin{array}{l}\text { The letters used in e-learning are simple } \\
\text { and easy for you to read. }\end{array}$ & 10 & 83.33 & Excellent \\
\hline 6 & $\begin{array}{l}\text { This e-learning is a learning guide } \\
\text { making it easier for you to understand } \\
\text { the material. }\end{array}$ & 10 & 83.33 & Excellent \\
\hline 7 & $\begin{array}{l}\text { Learning material in e-learning } \\
\text { encourages you to know more in } \\
\text { anecdote text learning and helps you } \\
\text { more easily understand anecdote text } \\
\text { material. }\end{array}$ & 9 & 75 & Good \\
\hline 8 & $\begin{array}{l}\text { The presentation of material in this e- } \\
\text { learning encourages you to discuss with } \\
\text { other friends. }\end{array}$ & 8 & 66.66 & Good \\
\hline 9 & $\begin{array}{l}\text { The presentation of material in e- } \\
\text { learning is easy for you to understand. }\end{array}$ & 10 & 83.33 & Excellent \\
\hline 10 & $\begin{array}{l}\text { Using e-learning with this anecdote text } \\
\text { material makes your learning more } \\
\text { directed and responsible in completing } \\
\text { assignments given by the teacher. }\end{array}$ & 10 & 83.33 & Excellent \\
\hline 11 & $\begin{array}{l}\text { Through e-learning this can make your } \\
\text { learning not boring. }\end{array}$ & 10 & 83.33 & Excellent \\
\hline 12 & $\begin{array}{l}\text { This e-learning makes you happy to } \\
\text { learn anecdote text material. }\end{array}$ & 11 & 91.66 & Excellent \\
\hline 13 & $\begin{array}{l}\text { Through this e-learning media you can } \\
\text { increase your interest and desire to learn. }\end{array}$ & 9 & 75 & Good \\
\hline 14 & $\begin{array}{l}\text { This e-learning includes formative tests } \\
\text { that can test how far your understanding }\end{array}$ & 10 & 83.33 & Excellent \\
\hline
\end{tabular}




\begin{tabular}{|l|l|l|l|l|} 
& $\begin{array}{l}\text { of e-learning based anecdote text } \\
\text { learning. }\end{array}$ & & Excellent \\
\hline 15 & $\begin{array}{l}\text { Online exam questions in e-learning } \\
\text { increase your understanding in anecdote } \\
\text { text material. }\end{array}$ & 11 & 91.66 & Excellent \\
\hline 16 & $\begin{array}{l}\text { This e-learning video is easy for you to } \\
\text { understand. }\end{array}$ & 10 & 83.33 & Excellent \\
\hline 17 & $\begin{array}{l}\text { Learning media e-learning makes you } \\
\text { think more creatively and responsibly } \\
\text { with your friends to do the assignments } \\
\text { given by the teacher. }\end{array}$ & 11 & 91.66 & Excellent \\
\hline 18 & $\begin{array}{l}\text { With this e-learning, you can easily } \\
\text { access specific information about } \\
\text { anecdote text material. }\end{array}$ & 11 & 91.66 & Excellent \\
\hline 19 & $\begin{array}{l}\text { This e-learning makes it easy for you to } \\
\text { ask directly if you don't understand } \\
\text { anecdote text material. }\end{array}$ & 11 & 91.66 & Excellent \\
\hline 20 & $\begin{array}{l}\text { This E-learning media is easy for you to } \\
\text { use. }\end{array}$ & 12 & 100 & Excellent \\
\hline Average & $\mathbf{2 0 1}$ & $\mathbf{8 3 . 7 4}$ &
\end{tabular}

Table 12. The Percentage Criteria of indicators occurrence on the E-Learning based Anecdote text learning that have been developed

\begin{tabular}{|l|l|l|}
\hline No. & Answer & Score \\
\hline A & Excellent & $81 \% \leq \mathrm{X}<100 \%$ \\
\hline B & Good & $61 \% \leq \mathrm{X}<80 \%$ \\
\hline C & Enough & $41 \% \leq \mathrm{X}<60 \%$ \\
\hline D & Fair & $21 \% \leq \mathrm{X}<40 \%$ \\
\hline E & Unsatisfied & $0 \% \leq \mathrm{X}<20 \%$ \\
\hline
\end{tabular}

(Sugiyono, 2012: 118)

To be clearer, the results of obtaining the graph data empirically can be seen in the following figure:

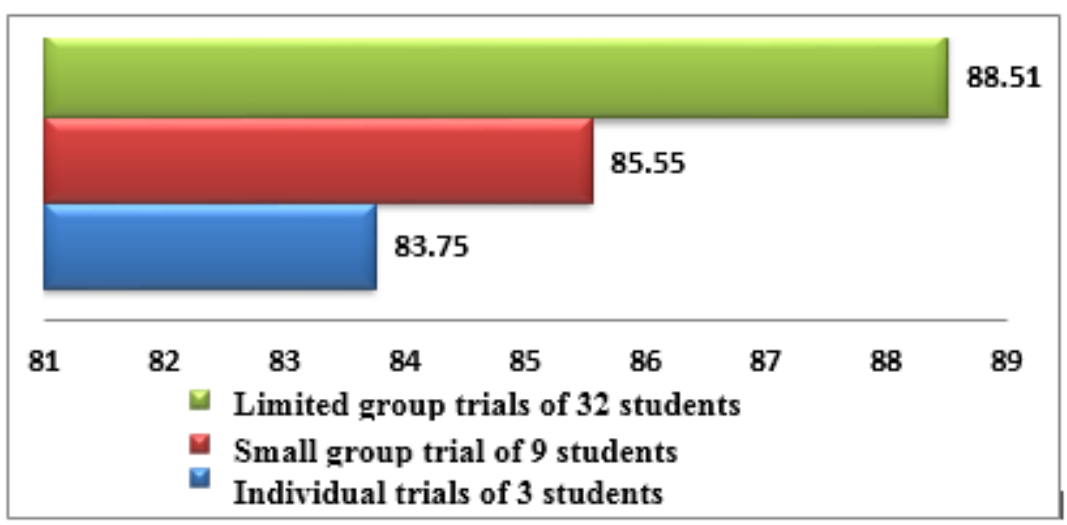

Figure 1. Trials of e-learning based anecdote text learning media products 
Figure 1 above, there are individual trial results in X grade student of Senior High School Harapan 3 Delitua showing e-learning based anecdote text learning media are in the "Excellent" category with an average percentage of $83.75 \%$. The results of small group trials in X grade Senior High School Harapan 3 Delitua showed that e-learning based anecdote text learning media was in the "Excellent" category with a percentage of $85.55 \%$. The results of limited field trials in X grade Senior High School Harapan 3 Delitua showed that the e-learning based anecdote text learning media was in the "Excellent" category with a percentage of $88.51 \%$. This shows that there is an increase and feasibility of e-learning based anecdote text learning media of X grade students Senior High School Harapan 3 Delitua.

Table 13. Frequency Distribution of Pretest Values

\begin{tabular}{|l|l|l|}
\hline Interval & Frequency & Percentage \\
\hline $60-65$ & 6 & $18,75 \%$ \\
\hline $66-70$ & 8 & $25 \%$ \\
\hline $71-75$ & 7 & $21,87 \%$ \\
\hline $76-80$ & 9 & $28,12 \%$ \\
\hline $81-85$ & 1 & $3,12 \%$ \\
\hline $86-90$ & 1 & $3,12 \%$ \\
\hline Total & $\mathbf{3 2}$ & $\mathbf{1 0 0 \%}$ \\
\hline
\end{tabular}

Frequency of Pretest Value

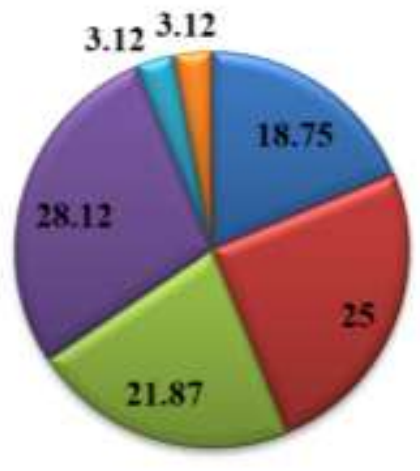

ail (6 Students)

a (8 Students)

'

'

II (1 Students)

in: (1 Students)

Figure 2. Frequency of Pretest Value in Percentage

Table 14. Posttest Value Frequency Distribution

\begin{tabular}{|l|l|l|}
\hline Interval & Frequency & Percentage \\
\hline $80-83$ & 5 & $15,62 \%$ \\
\hline $84-86$ & 7 & $21,87 \%$ \\
\hline $87-89$ & 0 & $0 \%$ \\
\hline $90-92$ & 8 & $25 \%$ \\
\hline $93-95$ & 7 & $21,87 \%$ \\
\hline $96-98$ & 0 & $0 \%$ \\
\hline $99-100$ & 5 & $14,28 \%$ \\
\hline Total & $\mathbf{3 2}$ & $\mathbf{1 0 0 \%}$ \\
\hline
\end{tabular}


Frequency of Post-test Value

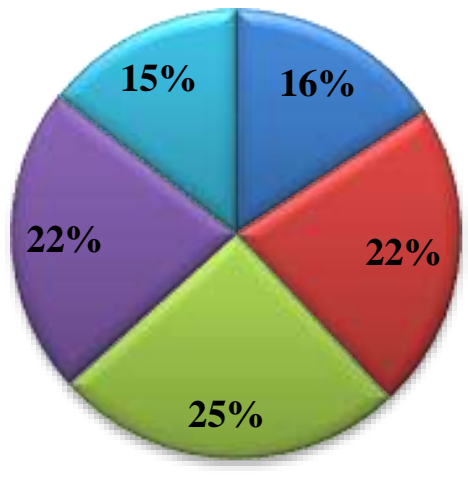

Posttest

田(5 Students)

田(7 Students)

四(8 Students)

回(7 Students)

回(5 Students)

Figure 3. Frequency of Posttest Value in Percentage

Table 15. Summary of Pretest and Posttest Values

\begin{tabular}{|l|l|l|l|}
\hline NO & Group & Average Score & Quarrel \\
\cline { 1 - 3 } & Before (Pretest) & 73,59 & \multirow{2}{*}{$\mathbf{6 , 4 1}$} \\
\hline 2 & After (Posttest) & 90 & \\
\hline
\end{tabular}

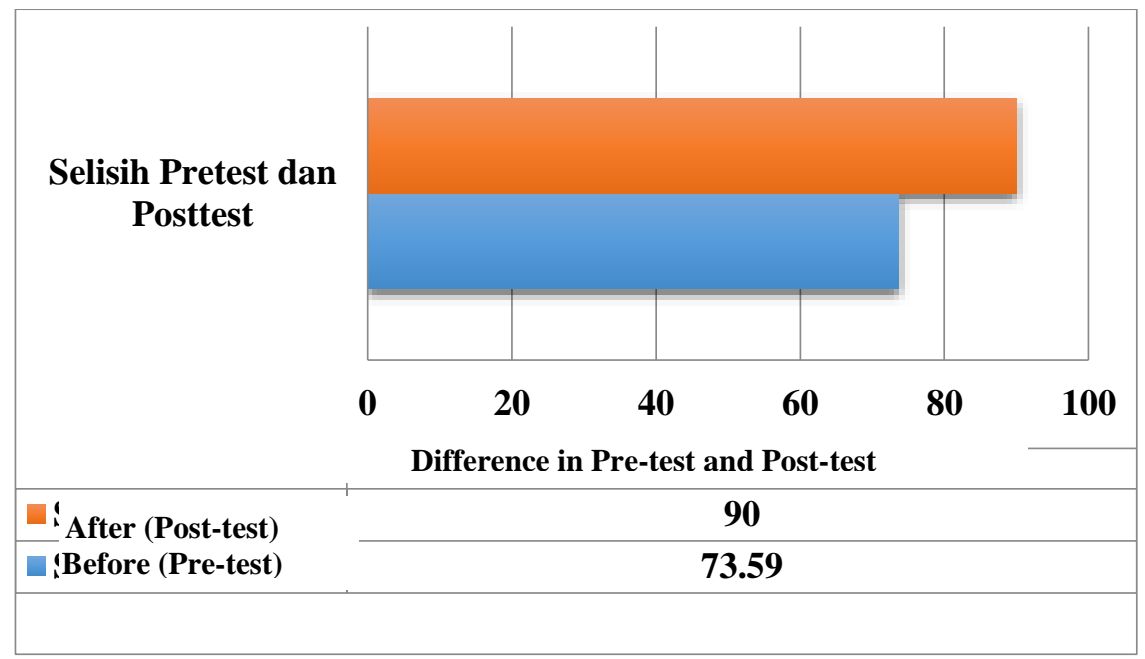

Figure 4. Average Pretest and Posttest Values of E-learning based anecdote text learning media for X Grade Students of Senior High School Harapan 3 Delitua

Based on the picture above, it can be concluded that learning using e-learning based anecdote text learning media can improve student learning outcomes in Indonesian language subjects. Furthermore, the effectiveness of e-learning based anecdote text learning media is obtained in the following way:

Effectiveness $=\frac{\text { Number of scores obtained }}{\text { Ideal number of scores }}: X 100 \%$

So that the errectiveness or e-rearning based anecdote text learning media gained a score of 2880 with an ideal score of 3200, then obtained 90 . While the effectiveness of not using e- 
Budapest International Research and Critics in Linguistics and Education (BirLE) Journal Volume 2, No 4, November 2019, Page: 272-286 e-ISSN: 2655-1470 (Online), p-ISSN: 2655-2647 (Print) www.bircu-journal.com/index.php/birle emails: birle.journal@gmail.com birle.journal.qa@gmail.com

learning based anecdote text learning media in the learning process was 2355 with an ideal score of 3200 , then obtained 73,59 . Based on the above calculation it is concluded that the elearning based anecdote text learning media that has been developed is more effective compared to student handbooks.

The research process "The Development of e-learning based anecdote text learning media of X Grade Students of Senior High School Harapan 3 Delitua" which has been carried out produces the final product of research in the form of e-learning based anecdote text learning media used by $\mathrm{X}$ grade students has shown excellent results. Pretest results showed an average grade of 73.59 categorized as "Good". Pretest results obtained, one student scored 90 score, 1 student got 85 score, Nine students got 80 score, Seven students got 75 score, eight students got 70 score, Three students got 65 score and 3 students got a 60 score, a total of 32 students. After using e-learning based anecdote text learning media there is an increase in the average value of students in the category of "Excellent" with an average 90 score. Based on these values there is a difference in the pretest and posttest scores of 16.41. The results of the posttest acquisition of $X$ grade students, 5 students got 100 score, seven students get 95 score, eight students get 90 score, seven students get 85 score, and five students get 80 score, there are a total of 32 students. E-learning based anecdote text learning media indicates that this media is excellent if implemented in learning anecdote text material.

\section{Conclusion}

It can be concluded that the use of e-learning based anecdote text learning media is more effective than non-e-learning based learning, this can be seen from the average results of the pretest and posttest and the achievement of the indicator value of students in using e-learning learning media.

\section{References}

Ambarita, B. (2018). Pengantar Ilmu Sastra. Bandung: Alfabeta.

Ambarita, B. (2016). Manajemen Pendidikan Dan Peningkatan Mutu. Bandung: Alfabeta.

Ambarita, B. (2016). Perilaku Dan Konflik Dalam Organisasi. Bandung: Alfabeta.

Arikunto, S. (2016). Dasar-Dasar Evaluasi Pendidikan. Jakarta: Bumi Aksara.

Bearne, E. (2003). Clashroom Interaction In Literacy. London: Open University Press.

Beslina. (2015). Pembelajaran Menulis Teks Anekdot Berbasis Kurikulum 2013, Jurnal Suluh Pendidikan FKIP-UHN 3(1):15-23

Dwiyogo, W. (2018). Pembelajaran Berbasis Blended Learning. Depok: Raja Grafindo.

Hanum, N. (2017). The Effetiveness Of E-Learning As Intructional Media (Evaluation Study Of E-Learning Instrucsional Model In SMK Telkom Sandhy Putra Purwokerto), Jurnal Pendidikan Vokasi 1(1):30-36

Irfan, P. (2017). Implementasi E-Learning Berbasis Website Sekolah Menengah Atas Negeri di Kabupaten Lombok Utara, Jurnal Konferensi Nasional Sistem \& Informatika 1(5):10-18.

Islamiyah, M. (2016). Efektifitas Pemanfaatan E-Learning Berbasis Website Terhadap Hasil Belajar Mahasiswa Stmik Asia Malang Pada Mata Kuliah Fisika Dasar, Jurnal Ilmiah teknologi dan Infoemasia ASIA (JITIKA) 10(1)25-33

Karyawati, E. (2015). Pengaruh Pembelajaran Elektronik (E-Learning) Terhadap Mutu Belajar Mahasiswa, Jurnal Penelitian Komunikasi 17(1):63-75 
Kemdikbud. 2015. Bahasa Indonesia Kelas X. Jakarta: Pusat Kurikulum dan Perbukuan.

Kucher, S. (2014). Dimension of Literacy. New York: Routledge.

Marisa, W. (2018). Korelasi Keterampilan Memahami Tes Anekdot Dengan Keterampilan Menulis Teks Anekdot Siswa Kelas X SMA Negeri 3 Padang Panjang., Jurnal Pendidikan Bahasa Dan Sastra Indonesia 7(3)110-116.

Shafwan. (2017). Berkelana Dalam Dunia Sastra. Medan: Penerbit Mitra.

Suyanto. (2000). Pendidikan Di Indonesia Memasuki Millenium Ke III. Yogyakarta: Adicita.

Sumiati. (2007). Metode Pembelajaran. Bandung: Wacana Prima.

Syafaruddin. (2013). Filsafat Ilmu. Bandung: Cipta Pustaka.

Tambunan, H. (2017). Model Pembelajaran Berbasis E-Learning Suatu Tawaran Pembelajaran Masa Kini Dan Masa Yang Akan Datang, UNIMED Jurnal 1-23

Tarigan, HG. (1985). Membaca Sebagai Suatu Keterampilan Berbahasa. Bandung: Angkasa. Tim Dosen Filsafat UGM. (2016). Filsafat Ilmu. Yogyakarta: Liberty.

Triyanti, N. (2018). Penerapan Metode Discovery Learning Pada Pembelajaran Menulis Teks Anekdot, Parole (Jurnal Pendidikan Bahasa dan Sastra Indonesia 3(4):70-82

Wardani, I. (2017). Studi Kasus Pembelajaran Menulis Teks Anekdot Pada Kurikulum 2013 Di SMA Negeri 1 Surakarta, Jurnal Aksara 2(1):60-62

Yoon, B. (2015). Critical Literacy Practice. New York: Springer. 